\title{
THE ROLE OF PHOSPHATES IN AGRICULTURE AND HIGHLIGHTING KEY ISSUES IN AGRICULTURE FROM A CLIMATE CHANGE PERSPECTIVE
}

\begin{abstract}
Lavinia Popescu ${ }^{1}$, Adela Sorinela Safta ${ }^{2}$
*Corresponding authorE-mail: saftaadela19@stud.ase.ro

A R T I C L E I N F O
Original Article
Received: 19 July 2021
Accepted: 20 November 2021
doi:10.5937/ekoPolj2104001P
UDC 551.583:631

Keywords:

agriculture, climate change, carbon emissions, phosphates

JEL: F1, Q2, C6

A B S T R A C T

This paper investigates in the foreground the state of agricultural systems in interdependence with climate change, a condition synec vanon of decarbonization of agriculture. The relationship between ecologically responsible agricultural systems places the innovative design of agricultural processes as the first factor in achieving the success of environmental responsibilities in addressing any agricultural processes customized to the area through the symbiosis between production in order to protect the biosphere. Thus, the constraints of reducing the consumption of chemical fertilizers in agriculture have gained new value at the same time as the interest of producers to gradually comply with the new more sustainable environmental requirements by optimizing synergies in the vision of the Common Agricultural Policy (CAP). The paper also identifies the risks of degradation of natural resources as an effect of environmental change, such as phosphorus, a much-needed element in agriculture, a declining global resource. From the empirical analysis of the analyzed sources we followed on the basis of statistical data a calibration of the risk trends generated by the impact of the adaptability of agriculture to environmental requirements, in achieving an agriculture designed for sustainability.
\end{abstract}

(C) 2021 EA. All rights reserved.

\section{Introduction}

The application of sustainable agricultural production may lead to an enlarge in carbon sequestration in soil through proper land management, thus making it feasible to improve its properties and the evolution of soil sequestration $\mathrm{C}$ being an important method and a priority.

1 Lavinia Popescu, PhD student, Bucharest University of Economic Studies, Doctoral of Economic School, Bucharest, Romania, E-mail: popesculavinia14@stud.ase.ro, ORCID ID (https://orcid.org/0000-0003-2545-7739)

2 Adela Sorinela Safta, PhD student, Bucharest University of Economic Studies, Doctoral of economic school, Bucharest, Romania; E-mail: saftaadela19@stud.ase.ro, ORCID ID (https://orcid.org/0000-0002-8321-2636)

http://ea.bg.ac.rs 
The challenge of bringing about changes in agricultural systems is both local and global. However, agricultural productivity is closely linked to possible disasters caused by climate change. Thus, efforts to adapt producers to the impact of adopting the new vision of agricultural policy are becoming more frequent and intense. The first part of the paper brings light on the effects of climate change and the need to adapt agricultural practices responsible for climate and the environment in agricultural structures in order to reduce greenhouse gas emissions. In order to limit these effects between the main technological options for reducing $\mathrm{CO}_{2}$ emissions and implicitly $\mathrm{CO}_{2}$ from the atmosphere, the appropriate use of agricultural land to provide sustainable products as argued by Andrei, J. V et al (2015). Political decisions such as the Council of Agriculture Ministers (2021) were also followed by measures to increase the limited quantities of ecosystems, compared to the general approach of the Council (progressive growth, starting at $22 \%$ in 2023 and reaching $25 \%$ in 2025), agreed issues of the European Commission (2021).

As an exception, the concept of sustainability was first introduced as a strategy to picture an example of a situation in the awareness of globalization and the increased result on it of the risk of loss of natural resources by intensifying the expansion activities of the industry. Considering the foreshadowing of a rising trend of agricultural productivity in development areas, the scenario of environmental impact with direct consequences on resources such as phosphorus, as a fertilizer raw material in agriculture, is inevitable. Thus a topic like resource depletion has a direct effect on the costs of phosphorusbased fertilizers. Fertilization with widely used phosphate has the advantage that phosphates have a much lower solubility, accumulating in the mineral fraction. Taking all these aspects into account, the key objective of the paper is to quantify the benefits of phosphorus in current agricultural practices at farm level. The case study on the simulation of phosphorus consumption was performed on maize production. In Romania, the fertilization of arable lands is practiced, especially with chemical fertilizers and there is a need more than ever to change the direction of agricultural methodologies depending on the effects of soil erosion. Ordinary agricultural practices are not adapted to the effects of climate change on small farms, because in the absence of widespread use of irrigation, the efficiency of agriculture in Romania is covered by dependence on climatic conditions, which is a stress factor for plants as claimed by Popescu et al. (2020).

Producers are concerned about measures to conserve natural flora and wildlife in the field of water, as well as pesticide residues in food and feed of plant and animal origin. As a result, pesticide use will be reduced, and human health and the environment will be protected from potential threats related to the use of pesticides by carrying out agricultural fertilization work in a timely manner may be a way to reduce the risks and their effects on human health and the environment (Ramírez, 2019).

Several measures, including, in particular, the use of antibiotics, should be used to prevent the occurrence and removal of hazardous organisms: crop rotation, the use of adequate cultivation techniques, why not an agricultural discipline related to production 
efficiency. This could include the use of several pesticides with different modes of action. Our research's risk methodology reveals the prevalence of acts that have an impact on biodiversity and natural capital resilience. What we set out to do is to provide a diagram of the risks of an agricultural economy caused by the assimilation of sustainability in the context of the demands imposed by climate change, but also of their global consequences, the continuous loss of natural resources. From this vantage point, we've discussed why it's critical to prioritize the risks in the agricultural system when it comes to fertilizers. As a result, several factors such as climate change, low yields associated with low selling prices, and agricultural commerce, as asserted by Nicholson, F et al., are not factors that determine fertilizer consumption (Nicholson et al., 2020).

The resilience of agriculture achieved through the convergence of the sustainability component is conditioned by the process levers necessary for alignment with cross compliance so that it becomes efficient, the process being cyclical, as argued by AznarSánchez, J. (2019).

The positive premises that foreshadow a large-scale symbiosis of the biosphere is a component of innovative research in various fields related to agriculture, the installation of new technologies being necessary to mitigate and adapt to climate change, and improve the quality of large-scale agriculture. Highlighting methodologies for farming does not necessarily follow a cliché, but a form of monitoring the minimum burden on biodiversity. But how do we potentiate the equation between reducing pollution, soil degradation and greenhouse gas emissions, maintaining biodiversity or whether constraints to maintain balance by improving soil fertility calls into question how much do we actually rely on fertilizers and how do we reduce consumption, what are the risks and returns (Johan F.M. Swinnen, 2015).

In recent decades, intensification practices in agriculture have contributed to increased yields. This has led to wide-ranging implications for shaping the ecological behavior of agricultural producers and achieving a more environmentally responsible agri-food model in the context of the CAP's greening policy (EC 2021).

\section{Materials and methods}

The statistical agricultural research inserted in the paper comes to evaluate the decarbonization potential of agriculture from another angle. Phosphorus is a necessary component of life. Phosphate mineral fertilizers have become the principal supply of phosphorus in world agricultural production, as well as the initial source of newly introduced phosphorus in the cycle, and there is no substitute for their usage in animal feed and fertilizers. The existing scenario, which includes waste and losses at every stage of the phosphorus life cycle, raises concerns about future phosphorus supply as well as water and soil contamination in the EU and around the world. The Brussels Advisory Communication on the Sustainable Usage of Phosphorus, CE (2013) 517, advises that measures be implemented to increase the efficiency of phosphorus use and recycling. Improvements in phosphorus consumption and recycling efficiency would 
also have a number of additional advantages, such as better soil management, which would enhance climate and biodiversity. (European Commission, 2021)

It is known that agriculture is a primary consumer of natural resources, a major user of the world's land area, according Fanelli R.M. (2019), directly dedicated to its use, a net consumer of water and accounts for most of the ammonia emission (Fanelli, 2019). Evaluations regardind the sustainability of the farm have been amply highlighted in scientific research contains that in order to be so framed in the vision of Girardin, P., (2021) a farm should be habitable, transmissible and reproducible from an ecological point of view economic and social (Girardin, 2012).

At the same time, Lynch et al (2021) emphasizes the huge role that agriculture plays in climate mitigation, the connection with strategies and mitigation capacity are closely linked (Lynch, 2021).

Climate targets have gradually become more prominent in the CAP over the last two decades. This section describes how climate concerns have been integrated into the CAP over time. Climate action was not a stated priority for the CAP before 2007 (European Commission, 2014)

However, certain measures and instruments that have been implemented could have some effect on climate change mitigation. For example, with the introduction of decoupled direct payments in 2003, intensive production was less encouraged. Evaluation of carbon storage and land use strategies in functional and competitive market economies have become increasingly visible in the concerns of scientific research, thus making way for the new era of less polluting agricultural development with very ambitious agricultural decarbonisation targets in a percentage of $40 \%$ by 2030, these being modified with a target of 55\% by 2050 (EC 2020).

Through phase 1, support in the agricultural system is conditioned by the unequivocal obligation imposed on farmers to manage agricultural land in a sustainable way. For the creation of storage conditions and sequestration of carbon in the soil between the obligations of good agricultural practices and environmental conditions (GAEC) are found and conditioning states to implement standards to reduce soil erosion and maintain organic matter levels and soil structure (Good agicultural and environmental conditions, 2021). Among the conditions of cross compliance, rules have also been introduced for the protection of permanent pastures, setting national limits for the percentage that could be plowed and thus generate $\mathrm{CO}_{2}$ emissions. As indicated by the Agricultural Organization of the United Nations, there are visible foreshadowing of increasing consumption due to population growth forecasts without excluding the need for demand for food resources or problems over time of renewable resources. In fact, the major challenges facing the agricultural sector today are offset by the need to balance the relationship of insufficient natural resources and the interdependence between increasing productivity and climate change. Trends in consumption, trade and productivity from an agricultural perspective as well as prices in the coming years until 2030 will reach inevitable changes. 
In this point, agriculture has to fulfill not only the ambitious depollution targets but also those of efficiency and sustainability in agriculture. The conclusion is that agriculture must become more efficient while improving agricultural productivity in order to reduce its impact on the environment.

Using high-quality plant protection solutions to acquire quality agricultural goods at affordable prices while posing minimal danger to human health and the environment is a crucial aspect in enhancing agricultural output and decreasing crop losses. As shown in Figure 1 at EU level, there is a significant share of agricultural products, imports being in real balance with exports but the concern is what has led to increased agricultural production on arable land used to increase the yield of agricultural production. This increase has often been attributed to high-yielding varieties, such as wheat or corn.

Figure 1. Tonnes (grain equivalent) import/export from 2017 to 2020 (in 1,000 euros)

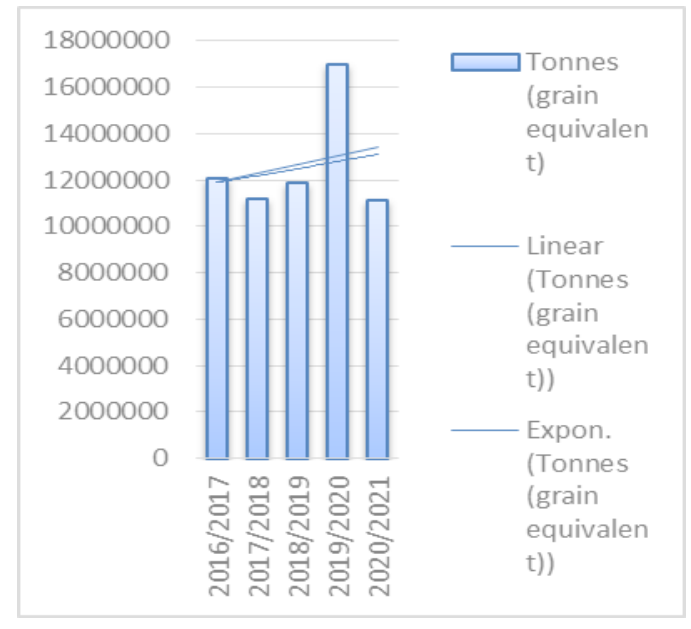

(a) Tonnes (grain equivalent) export

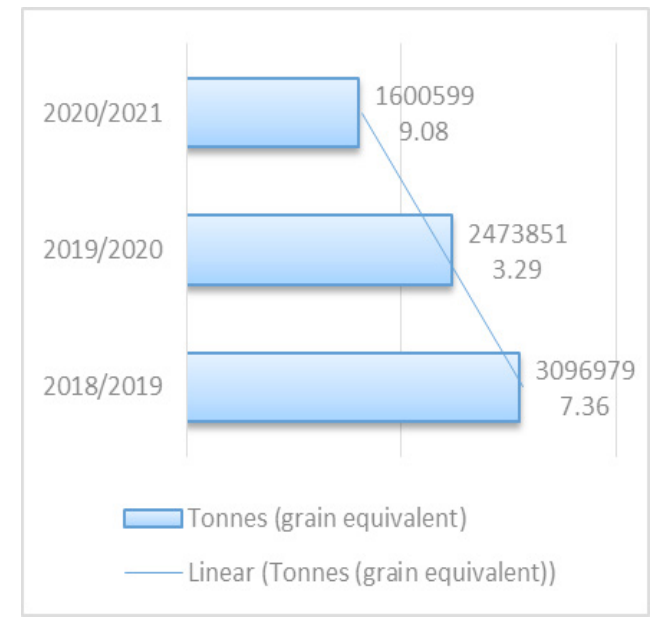

(b) Tonnes (grain equivalent) import

Sources: Eurostat data (2020) Directorate General for Agriculture and Rural Development

However, in order to achieve their high yields, the new varieties required large amounts of chemical fertilizers and pesticides, raising concerns about costs and potential environmental harm.

The largest shares of land sown with maize and wheat, 44 percent and 31 percent of the total area under cereals, respectively, belonged to products that are on the one hand a resource for food security of exports to the population, feed, and training, and on the other hand a resource for food security of exports to the population, feed, and training.

The main quantitative methods considered in the impact assessment concerned the counterfactual assessment method. The method of counterfactual impact assessment applied at the level of micro-data specific to those instruments relevant to this field, aim to allow quantification of the extent to which a particular monitored indicator produces 
effects and may aim to identify the direction of the link and the impact of reducing resources phosphorus-based fertilizers on yields in the case study chosen corn production. The method used is difference-in-differences (DID). (Constantin Anghelache et al, 2019)

Availability of the characteristics observed before the intervention takes place the advantage is that this method does not require the estimation of complex data structures, but only aggregated data. In order to apply the evaluation methodology counterfactual impact was necessary to collect specific micro-data at the level of statistical tools fertilizers including phosphorus used in maize production, maize production in the period established from 2011-2020, and other information such as the percentage of phosphorus used in estimated fertilization formula, determined on the basis of the fertilization formula with $\mathrm{N}$. The data sources were administrative, it should also be noted that the estimates of the net impact of this assessment will not be aggregated globally, but regionally to maize production of Romania.

The counterfactual scenario required was the basis for assessing the estimated regression of phosphorus resources.

In fact, in collecting and analyzing the data, in order to carry out the case study we compiled qualitative and quantitative procedures related to the large production of maize. How the crops react to phosphate fertilizers is highlighted below. If the level of $\mathrm{P}$ available in the soil is not suitable for optimal crop growth, use phosphate fertilizers to ensure adequate amounts of this nutrient in the solution phase. Terminology and sources of phosphate fertilizer from the market. Understanding the terminology and dosage used can help increase yields. An example of calculation refers to a farm that has an agricultural area of only 0.4 ha cultivated with corn, which we indicated in a simulation of fertilizer consumption in this case phosphorus. In this case the maximum amount of nitrogen that can be applied if an agrochemical study is not performed.

As previously stated, phosphates are utilized in conjunction with other substances on a 0.4 ha corn-growing farm; in this situation, the maximum amount of nitrogen that can be applied is:

$$
0.4 \text { (ha of corn) x } 130 \mathrm{Kg} \mathrm{N} / \text { ha / year) }=52 \mathrm{~kg} \mathrm{~N} / \text { year. }
$$

The simple superphosphate requirement is calculated taking into account the active substance concentration of $16-18 \% \mathrm{P}_{2} \mathrm{O}_{5}$ or $46 \%$ triple superphosphate $\left(\mathrm{P}_{2} \mathrm{O}_{5}\right)$. The percentage resulting from dividing $\mathrm{N}$ with phosphorus,

$18,545 \div 5096=3,64 \%$ the percentage between $\mathrm{N}$ used and phosphorus was thus obtained $130 \div 3,64 \%=35,72$

$$
0.4 \text { (ha of corn) } x 35,72 \mathrm{Kg} \mathrm{P}_{2} \mathrm{O}_{5} / \text { ha } / \text { year) }=14,30 \mathrm{~kg} \mathrm{P}_{2} \mathrm{O}_{5} / \text { year. }
$$

If at 0.4 ha $14.30 \mathrm{~kg} \mathrm{P}_{2} \mathrm{O}_{5} /$ year is used then at 1 ha $14.30 \times 2.5=35.72 \mathrm{~kg} \mathrm{P}_{2} \mathrm{O}_{5} /$ year is used the agricultural area used for maize production in Romania from 2007 to 2019. The land covered for maize production was the largest in 2012, with 2.73 million hectares and the smallest in 2010, with 2.1 million hectares. 
Thus, it results as an approximate simulation that at 3 million hectares the phosphorus needs are very high of approximately 42.864 thousand $\mathrm{kg} / 1000$ ha. $25 \% \mathrm{P}_{2} \mathrm{O}_{5}$ Phosphorus expressed as $\mathrm{P}_{2} \mathrm{O}_{5}$ soluble in neutral ammonium citrate, in which at least $93 \%$ of the declared content of $\mathrm{P}_{2} \mathrm{O}_{5}$ is soluble in water.

The water solubility quality of phosphorus pentoxide entails the qualities of using mineral fertilizers ( $\mathrm{N}$ and $\mathrm{P}$ ) given these characteristics as follows Limiting the risks of groundwater pollution through the reduced mobility of phosphorus, properly dosed, which makes it possible, on sandy soils, very permeable, to allow the passage of fertilizer particles but without absorbing them; On the other hand, in the case of surface waters, the risk of phosphate pollution increases, given the erosive runoff processes that produce the transport and accumulation of phosphate-laden soil particles in surface waters.

In order to ensure a high agronomic yield, mineral fertilizers must be applied in addition to natural sources, the double effect also having the purpose of protecting the environment against chemical pollution such as nitrate pollution of water. That is why an increased share in weed control in vegetation is given by the stage of the plant for the application of fertilizer on crops, and because the role of fertilizer is to act on the bacterium nitrosomonas by keeping it inactive. By maintaining nitrogen $\left(\mathrm{NH}_{4}+\right)$ in a stable form for longer, exposure to leachate and denitrification losses is limited. The aim is for the Nitrogen applied to the crop to remain for a long time at the level of the plants in order to increase the production potential. The optimal efficiency of fertilizer application is conditioned by the interaction of fertilizers without stress conditions.

\section{Results}

The transition to sustainable food systems, especially through the transition to organic farms, will bring new opportunities to farmers and operators throughout the food supply chain, generating both healthy food and lower environmental costs. EU regions that produce arable crops tend to stabilize phosphorus levels in the soil, but continue to depend on the application of phosphorus mineral fertilizers (Popescu L. et al., 2020).

Soil erosion and percolation, as well as ineffective manure, biodegradable waste, and wastewater, are all major sources of useful phosphorus loss. Water is used extensively in the extraction and processing of phosphate rocks as a raw material. As a result, while contemporary mines can reuse $95 \%$ of the water they take in, this is not the case in all cases because there are no ways for extracting phosphorus from these waters. Furthermore, there is a possibility of very acidic treatment water leakage or infiltration, particularly from basins atop phosphogypsum stacks, which might damage aquatic environments.

Water supply can be a significant limiting factor in the development of phosphate extraction because phosphate rock formations are commonly found in water-scarce areas. The extraction process consumes a lot of energy, which has a direct impact on the cost of production. The rise in phosphate rock prices is largely due to supply and demand, with one element being increased demand owing to biofuel crops. 
They also reflect food costs and may be a modest contributor to rising food costs. In this regard, we underline that agricultural systems as a whole require careful consideration; for example, we mention the necessity for phosphorus (P) for plant advantages both during early phases of plant development and during maturation. Among the direct effects on plants by performing phosphorus fertilization is to ensure good root growth in immature plants, reduce the maturation period and thus improve the stress resistance of the plant. Also the presence of phosphorus is a necessary component for storage and supply of cell energy.

On the other hand, the lack or insufficiency of phosphorus (P) leads to a slowdown in the process of root growth, and the leaves turn purple in shades of purple. It delays flowering and ripening, and production and quality are affected. In order to ensure the efficient and economically viable protection of agricultural crops, plant protection products should be applied only when strictly necessary, when the conditions for the occurrence of harmful organisms are met.

Figure 2. Global fertilizer use for corn from 2011 to 2021 (in 1,000 metric tons)

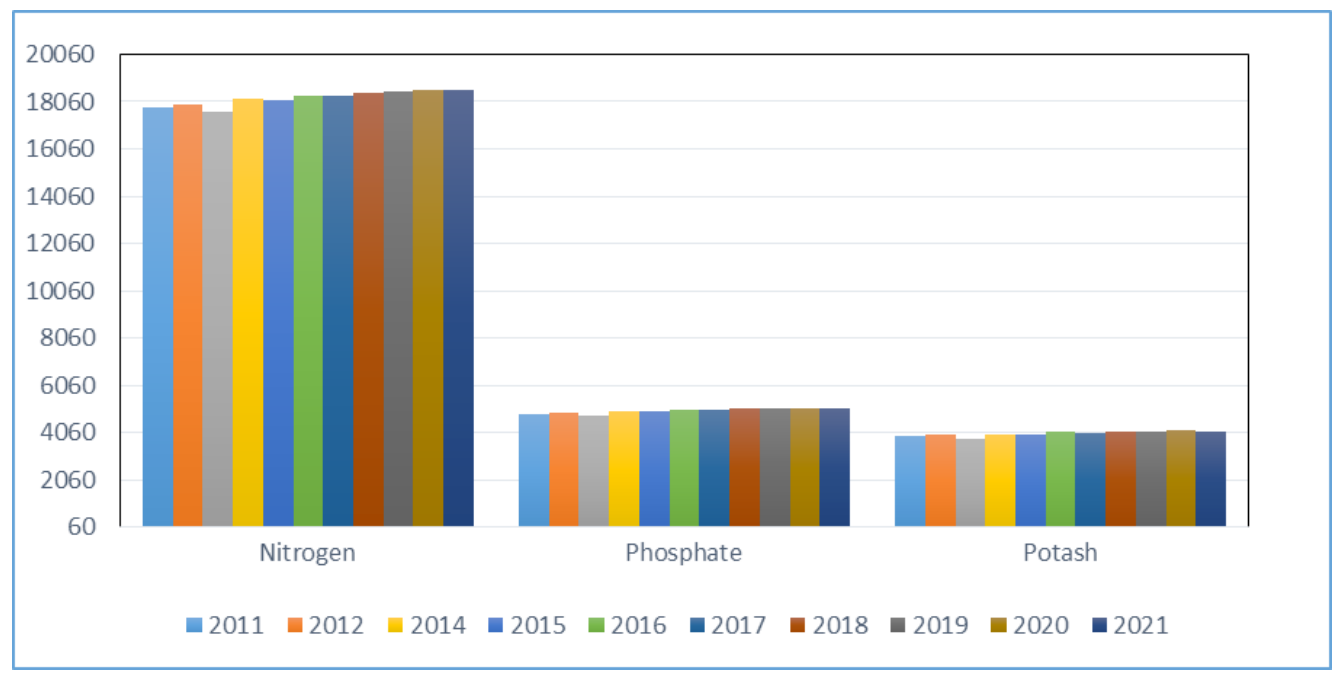

Sources https://www.statista.com/statistics/201092/global-fertilizer-use-for-corn-from2010/\#statistic

In the statistical example presented in Figure 2 is highlighted a projection on the global consumption of certain types of fertilizers for crops of corn nitrogen phosphate, potassium between 2011 and 2021. We conclude from the analysis that in 2018, it was expected o the global use of approximately 27.6 million metric tons of fertilizers in maize production. Also the Figure 3 (b) statistic presents the value of maize or corn exported from Romania annually from 2012 to 2020. Exports of maize were valued at approximately one billion euros in 2020 (Ramírez,2019). 
Analyzing the information we notice a sudden rise in corn production which means not only the increase in the need for consumption but also the development of sales marketing on demand corn, the increases being due to high yielding varieties and appropriate fertilization.

Figure 3. Value of maize or corn exported from Romania from 2012 to 2020 (in 1,000 euros)

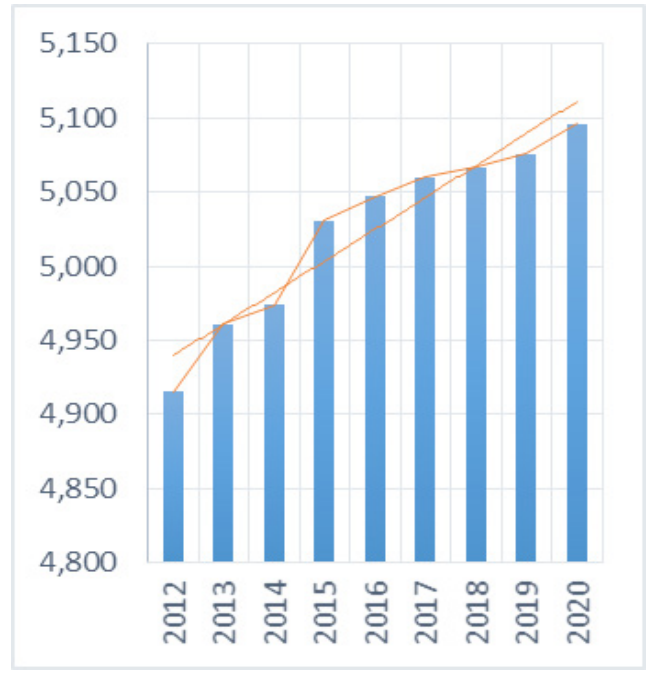

(a) phosphate fertilizer use for corn from 2011 to 2021

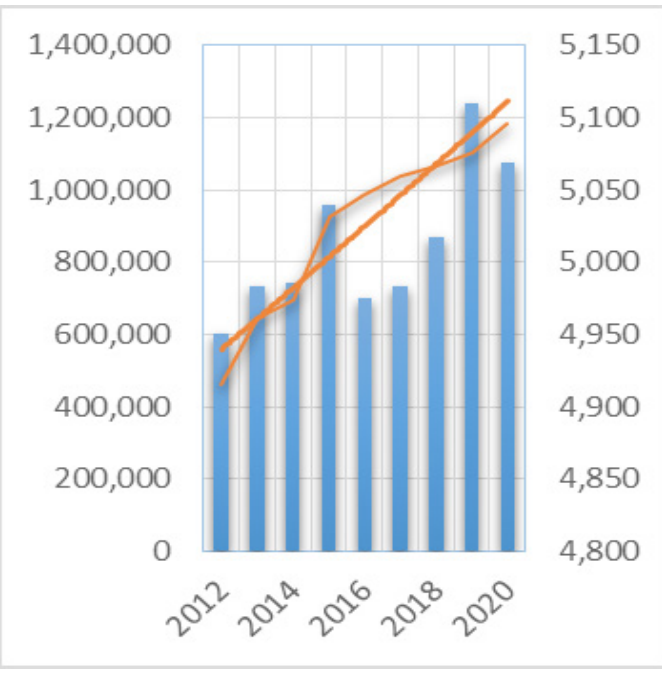

(b) Value of maize or corn exported from Romania from 2012 to 2020

Sources: own analysis

This statistic illustrates projections for the worldwide use of fertilizers from 2011 to 2021, for corn. For the year 2018, a global fertilizer use of approximately 27.6 million metric tons is projected for corn. Also the Figure $3(a, b)$ statistic presents the value of maize or corn exported from Romania annually from 2012 to 2020. Exports of maize were valued at approximately one billion euros in 2020 .

Because phosphorus cannot exist alone in nature and forms compounds of apatite $\left(\mathrm{Ca}_{5}\right.$ $\left.\left(\mathrm{PO}_{4}\right) 3 \mathrm{~F}\right)$ and phosphorite $\left(\mathrm{Ca} 3\left(\mathrm{PO}_{4}\right) 2\right)$, the transition to a mode of use in agricultural production as fertilizer necessitates a combination of elements highlighted in Table 1. At the same time, phosphorus must be used in accordance with the other nutrients required by plants.

Nitrogen fertilizers have a high solubility and have the quality of providing almost all the nutrients needed by plants in a form that allows their direct and easy absorption. Table 1 shows Simple phosphate fertilizers highlighting the nutrient content; the forms and solubilities of nutrients; 
Table 1. Simple phosphate fertilizers

\begin{tabular}{|l|l|l|l|}
\hline Title & $\begin{array}{l}\text { Data - method of obtaining } \\
\text { components }\end{array}$ & $\begin{array}{l}\text { Nutrient content; the forms } \\
\text { and solubilities of nutrients; }\end{array}$ \\
\hline $\begin{array}{l}\text { Partially } \\
\text { solubilized } \\
\text { phosphate } \\
\text { rock (active } \\
\text { phosphori) }\end{array}$ & $\begin{array}{l}\text { Product obtained by } \\
\text { gartial solubilization of } \\
\text { with sulfuric or phosphoric } \\
\text { acid, containing as main } \\
\text { component monocalcium } \\
\text { phosphate, tricalcium } \\
\text { phosphate and calcium } \\
\text { sulphate }\end{array}$ & $\begin{array}{l}\text { 20\% } \mathrm{P}_{2} \mathrm{O}_{5} \text { Phosphorus } \\
\text { expressed as soluble } \mathrm{P}_{2} \mathrm{O}_{5} \\
\text { in mineral acids, of which } \\
\text { at least } 40 \% \text { of the declared } \\
\text { content is soluble in water. } \\
\text { Particle size: - at least } 98 \% \text { of } \\
\text { the product must pass through } \\
\text { the meshes of a } 0,630 \mathrm{~mm} \\
\text { sieve }\end{array}$ & $\begin{array}{l}\text { Total phosphorus pentoxide } \\
\text { (soluble in mineral acids). } \\
\text { Water-soluble phosphorus } \\
\text { pentoxide. }\end{array}$ \\
\hline $\begin{array}{l}\text { Ground } \\
\text { phosphate } \\
\text { rock }\end{array}$ & $\begin{array}{l}\text { grinding phosphate rock, } \\
\text { which contains as main } \\
\text { components tricalcium } \\
\text { phosphate and calcium } \\
\text { carbonate }\end{array}$ & $\begin{array}{l}25 \% \mathrm{P}_{2} \mathrm{O}_{5} \\
\text { Phosphorus expressed as } \\
\text { mineral acid soluble } \mathrm{P}_{2} \mathrm{O}_{5}, \\
\text { of which at least } 55 \% \text { of the } \\
\text { declared } \mathrm{P}_{2} \mathrm{O}_{5} \text { content }\end{array}$ & $\begin{array}{l}\text { Total phosphorus pentoxide } \\
\text { (soluble in mineral acids) } \\
\text { is soluble in 2\% formic } \\
\text { acid. The mass percentage } \\
\text { corresponding to the } \\
\text { material passing through a } \\
0.063 \text { mm sieve }\end{array}$ \\
\hline
\end{tabular}

Source: MADR - Annex Decision on establishing the conditions for placing on the market chemical fertilizers from domestic production and imports

Thomas slag, calcined phosphates, and calcium and aluminum phosphate must not be present in an NPK fertilizer comprising pulverized or partially solubilized phosphate rock. It has to be declared based on the solubility. Phosphorus mineral fertilizers have a much lower solubility than potassium mineral fertilizers $(10-20 \%$ in the first year after application for phosphorus and $30-40 \%$ for potassium), accumulating in the colloidal mineral formations of the soil before being blocked under in the form of calcium, sparingly soluble magnesium phosphates.

Figure 3 depicts phosphorus deficit in a maize crop. Phosphates have a far lower solubility, thus they accumulate in the soil's colloidal mineral fraction, where they are reversibly adsorbed. Phosphorus fertilizers are chemicals that contain phosphorus in the form of anions: mono-, di- or triphosphate. The expression, according to international norms, is done in percent of phosphorus pentoxide $\left(\mathrm{P}_{2} \mathrm{O}_{5}\right)$. Nitrophosphates are complex fertilizers that are obtained by attacking phosphate rock with nitric acid. Several NP or NPK types can be obtained by this process. The most used are: K-22-22-0, K-23-23-0, K-27-13.5-0, K-22-11-11 and K-16-16-16. They contain up to 70\% water-soluble $\mathrm{P}_{2} \mathrm{O}_{5}$ relative to the total content. It is generally applied to basic fertilizers.

\section{Discussions}

In line with the objective of the current paper, a statistical analysis was performed to materialize the key problems of agricultural systems to climate change and to explore the implications of fertilization techniques, highlighting the depletion over time of phosphorus resources so used in production agricultural. 
The data and information presented were collected from open access resources on official EU websites and from scientific papers on the subject. The availability of data is meant to provide transparency in the efforts of Eurostat and the OECD as well as the EU, on issues of Agricultural Policy.

The first effect of the CAP, characterized by increased flexibility, created the possibility for Member States to design their own individual program adapted to rural development for 2014-2020 in accordance with EU regulations no. 1303, 1305 and 1306/2013 (E.P., 2020).

The necessary changes to synthesize the data visualization consist in the mathematical mediation, where appropriate, to represent the annual numbers for the analyzed period 2015 - 2019 respectively, in some cases, were expressed at import-export rates to agricultural production of cereals in which it is mandatory, from the perspective of analyzing resources such as phosphorus (Report, 2020, European Commission; World fertilizer trends and outlook to 2022).

\section{Conclusions}

These permanent monitoring by the scientific elite as well as by the EU authorities in linking the transition to decarbonization of agriculture have the effect of monitoring the economic vulnerability of farms (Volkov et al., 2019).

Agriculture and horticulture pose a threat to lakes and rivers by polluting them. Mineral fertilizers, it can be stated, have an impact on regional imbalances in this context. Phosphorus fertilizer, unlike nitrogen fertilizer, is derived from rock phosphate and cannot be chemically produced. The shortage of phosphorus may result in a rise in market price as a result of its economic impact. Production may be reduced as the price of phosphorus rises, and competitive consumers may notice the impacts. Farmers' costs are growing due to increased market prices, which has an economic consequence. When there is a lot of demand, the majority of the immigrant workers will be able to find work.

Phosphorus is a valuable commodity that is commonly used in agriculture. As a result, after the emergence of extremely high phosphorus consumption, consumers faced higher expenses, farmers faced higher costs, and farmers faced higher revenues. The amount of phosphate in the soil that has been water-solubilized is mostly absorbed by plant roots; the amount induced by water movement in the deeper layers of the soil is relatively modest. Phosphorus improves plant health, benefits the environment by reducing leaching and reducing the amount of nitrates in groundwater and has the role of reducing the emission of harmful greenhouse gases into the atmosphere. For example: fertilizers in which $\mathrm{P}_{2} \mathrm{O}_{5}$ predominates are more suitable for straw cereals before sowing, those with a nitrogen ratio are suitable for technical crops, etc. The properties of the soil influence the use of fertilizers, irrigation and fertilization can be combined, obtaining a simultaneous supply of water and nutrients.

A possible regression of pesticide use without excessive decrease in yields pursued by systemic forecasts can be achieved even without reversing the decrease in production potential and production losses by cyclically monitoring yield control, exploring and improving 
more disease-tolerant varieties. The effects of such an investigation bring to the fore not only the recovery of yields through improved varieties but the use of a necessary consumption of phosphorus-based fertilizers adapted to climate practices, to better capitalize on the potential of resources used as mineral fertilizers such as phosphorus or an indispensable resource in world agricultural production. As we can see, there are many CAP measures that are used in order to contribute to climate change activities through green payments under the CAP conditions imposed on farmers through cross compliance, as well as voluntary measures under rural development policy. The question is whether climate change because farmers are more than an awareness of the depletion of natural resources with the concern to provide sustainable and healthy production for export, and why not to reduce grain imports.

The paper also identifies that the CAP is accountable to farmers for cross-compliance obligations and good agricultural practices in relation to the EU's agricultural capacity, especially with regard to other effects of climate change, and from this angle the reduction of resources such as phosphorus is a concern. However, from a climate change perspective, it should be a mandatory approach for all assets agricultural authorities.

The current CAP will set targets for how EU agricultural systems are able to meet the prevailing challenges, especially those related to climate change. The key issue of the future policy is the ability of the farmer to mitigate the environmental compromise through sustainable practices and constant adaptation (Wieliczko, 2019). Agriculture requires a repositioning towards the other actors of the economy to behavioral changes in the responsibility of farmers' actions in accordance with the appropriate environmental requirements. Economic performance has consequences for innovation decisions, shaping production structure and causing structural change, but when it comes to depleting the resources used in agriculture the first option is the systemic use of these products such as phosphate (DeBoe et al., 2020).

\section{Conflict of interests}

The authors declare no conflict of interest.

\section{References}

1. Andrei, J. V., Dusmanescu, D., \& Mieila, M. (2015). The influences of the cultural models on agricultural production structures in Romania and some EU-28 countries-a perspective. Economics of Agriculture, 62(297-2016-3679), 293-307

2. Agri-food data portal, and European agriculture and common agricultural policy,https://agridata.ec.europa.eu/extensions/DashboardCereals/Cereals Trade. html, (accessed 12 June 2021)

3. Aznar-Sánchez, J. A., Piquer-Rodríguez, M., Velasco-Muñoz, J. F., \& ManzanoAgugliaro, F. (2019). Worldwide research trends on sustainable land use in agriculture. Land Use Policy, 87, 104069.

4. Brussels, 8.7.2013 COM (2013) 517. (accessed 12 June 2021)Advisory Communication on the sustainable use of phosphorus, https://ec.europa.eu/ environment/consultations/pdf/phosphorus/EN.pdf 
5. Constantin Anghelache et al, (2019) Econometrie, Ed.Artifex, pp.35-78, ISBN 978-973-7631-51-0. Bucharest, Romania.

6. Directive 2009/128 / EC of the European Parliament and of the Council of 21 October 2009 establishing a framework for Community action to achieve a sustainable use of pesticides, published in the Official Journal of the European Union, L series, no. 309 of 24.11.2009 and of the Corrigendum to Directive 2009/128 / EC of the European Parliament and of the Council of 21 October 2009 establishing a framework for Community action for the sustainable use of pesticides, published in the Official Journal of the European Union, L series , no. 161, from 29.06.2010.

7. European Commission, (2014. Environment Action Programme to 2020, Brussels, (accessed 12 June 2021) https://ec.europa.eu/environment/action-programme/

8. European Commission, 2021. Forging a climate-resilient Europe - the new EU Strategy on Adaptation to Climate Change, Brussels: COM 82. (accessed 12 June 2021) https://www.europarl.europa.eu/factsheets/en/sheet/110/second-pillar-ofthe-cap-rural-development-policy

9. European Commission, framework. The current CAP framework was established, in particular, by Regulations (EU) No 1303/20131, (EU) No 1305/20132, (EU) No 1306/20133, (EU) No 1307/20134 and (EU) No 1308/20135 of the European Parliament and of the Council. (accessed 12 June 2021) https://data.consilium. europa.eu/doc/document/PE-29-2020-INIT/en/pdf.

10. European Commission, 2014. Environment Action Programme to 2020, Brussels, (accessed 12 June 2021) https://ec.europa.eu/environment/action-programme/

11. European Commission, 2017. Evaluation study of the payment for agricultural practices beneficial for the climate and the environment, Brussels: Alliance Environment and the Thunen Institute, (accessed 12 June 2021) https:/op.europa. eu/en/publication-detail/-/publication/598b81ff-dfbc-11e7-9749-01aa75ed71a1

12. Fanelli, R. M. (2019). The (un) sustainability of the land use practices and agricultural production in EU countries. International journal of environmental studies, 76(2), 273-294. Doi: https://doi.org/10.1080/00207233.2018.1560761

13. Girardin, P., (2012), Indicators:Tools to evaluate the environmental impacts of farming systems. Journal of Sustainable Agriculture 13, 5-21. Doi:10.1300/ JO64v13n04_03.

14. Good agicultural and environmental conditions, abbreviated as GAEC, refers to a set of European Union (EU) standards (described in Annex II of Council Regulation No.1306/2013 defined at national or regional level), aiming to achieve a sustainable agriculture.2, (accessed 12 June 2021) https://marswiki.jrc.ec.europa.eu/wikicap/ index.php/Good_Agricultural_and_Environmental_Conditions_(GAEC).

15. Gwen DeBoe et al, (2020) Reforming Agricultural Policies Will Help to Improve Environmental Performance, EuroChoices, Volume19, Issue 1, April 2020, pp 3035, https://doi.org/10.1111/1746-692X.12247 
16. Johan F.M. Swinnen (2011) The food crises, mass media and the political economy of policy analysis and communication, European Review of Agricultural Economics, Volume 38, Issue 3, August 2011, Pages 409-426, https://doi.org/10.1093/erae/jbr020.

17. Lynch, J., Cain, M., Frame, D., \& Pierrehumbert, R. (2021). Agriculture's contribution to climate change and role in mitigation is distinct from predominantly fossil CO2-emitting sectors. Frontiers in sustainable food systems, 4, 300. doi: 10.3389/fsufs. 2020.518039

18. Nicholson, F., Laursen, R.K., Cassidy, R., Farrow, L., Tendler, L., Williams, J., Surdyk, N., Velthof, G., 2020. How can decision support tools help reduce nitrate and pesticide pollution from agriculture? A literature review and practical insights from the EU FAIRWAY project, Water (Switzerland), Volume 12, Issue 3, 1 March 2020, Article number 768

19. Popescu L. et al., (2020), Considerations regarding improving the ecological and environmental performance of agriculture, ICBE2020, Proceedings of the International Conference on Business Excellence Volume 14 (2020): Issue 1 (July 2020), "Business Revolution in the Digital Era", Published Online 27 Jul 2020, DOI: https://doi.org/10.2478/picbe-2020-0066

20. Ramírez, P. B., Calderón, F. J., Fonte, S. J., \& Bonilla, C. A. (2019). Environmental controls and long-term changes on carbon stocks under agricultural lands. Soil and Tillage Research, 186, 310-321.

21. Regulations Amendin (EU), No 1305/2013, (EU) No 1306/2013 and (EU) No $1307 / 2013$ as regards resources and application in the years 2021 and 2022 and Regulation (EU) No 1308/2013 as regards resources and the distribution of such support in respect of the years 2021 an 2022. (accessed 12 June 2021) https://data. consilium.europa.eu/doc/document/ST-13818-2020-INIT/en/pdf.

22. Report (2020), European Commission, Eurostat and Directorate General for Agriculture and Rural Development https://ec.europa.eu/info/departments/ agriculture-and-rural-development_en.

23. World fertilizer trends and outlook to 2022, Demand for fertilizer use Forecasts of world demand for nitrogen, phosphorus and potassium for fertilizer use, up to 2022, https:/www.eea.europa.eu/data-and-maps/indicators/total-fertiliserconsumption-outlook-from-fao/total-fertiliser-consumption-outlook-from

24. Volkov, A., Balezentis, T., Morkunas, M., Streimikiene, D., 2019. Who Benefits from CAP? The Wa the Direct Payments System ImpactsSocioeconomic Sustainability of Small Farms. Sustainability 11, 2112. https://doi.org/10.3390/ su11072112.

25. Wieliczko, B., 2019. Planned Shape of the CAP 2021-2027 versus Globalisation and Integration Processes. Zeszyty Naukowe SGGW w Warszawie - Problemy Rolnictwa Światowego, 19(34), 224-232. 